\title{
Preparation, characterization, antibacterial and antifungal activities of some transition metal complexes with novel Schiff base ligand derived from $\mathrm{N}$-amino rhodanine
}

\author{
Sara Ansari ${ }^{a}$, Felora Heshmatpour ${ }^{a}$, Soleiman Mahjoub ${ }^{\text {b* }}$ \\ ${ }^{a}$ Department of Chemistry, K.N. Toosi University of Technology, P.O. Box - 1618, Tehran 15418, Iran. \\ saragreen.6677@gmail.com \\ ${ }^{b}$ Babol University of Medical Sciences, Faculty of Medicine, Department of Biochemistry-Biophysics, Babol, \\ Iran. \\ *Corresponding author: smahjoub20@gmail.com
}

\begin{abstract}
The Schiff base ligand (E)-3-(2-methoxy benzylidene amino)-2-thioxothiazolidin-4-one (L), was prepared from N-amino rhodanine and 2-methoxy benzaldehyde. Moreover, Its complexes were synthesized by mixing metal chloride Co(II), $\mathrm{Cu}(\mathrm{II}), \mathrm{Ni}(\mathrm{II})$ with the prepared Schiff base ligand. These compounds were characterized by FTIR, ${ }^{1} \mathrm{H}$ NMR, and elemental analysis. The antimicrobial activity of the ligand and its complexes were tested using four pathogenic bacterial and two fungal species. The bacterial species used in the screening were Salmonella typhi and Vibrio cholera (gram negative) and Staphylococcus aureus and Bacillus subtilis (gram-positive). The fungal species were Aspergillus flavus and Aspergillus nigar. The antimicrobial activities of the ligand and its metal complexes were studied by disc agar diffusion method and compared with Ampicillin. Diameter of inhibition zone $(\mathrm{mm})$ including the disc diameter was measured for each treatment. The findings indicated that the CuL, NiL and CoL complexes have good biological activity but the ligand (L) did not had any activity against the microorganisms under identical experimental conditions.
\end{abstract}

\section{Indexing terms/Keywords}

Synthesis; characterization; antimicrobial activity; N-amino rhodanine; schiff-base.

\section{Council for Innovative Research}

Peer Review Research Publishing System

\section{Journal: Journal of Advances in Chemistry}

Vol 11, No. 7

editorjaconline@gmail.com, www.cirjac.com 


\section{INTRODUCTION}

Rhodanine and its derivatives have received much attention due to their significant biological activities such as antibacterial [1,2], antifungal [3], antidiabetic [4], anti-HIV [5,6] antititubercular [7] and antiparasitic [8]. Moreover, Rhodanine derivatives have been reported as Hepatitis $\mathrm{C}$ virus (HCV) protease agent inhibitor [9]. Rhodanine is a heterocyclic compound which belongs to the thiazolidinones group. Thiazolidinone compounds, have been investigated because of having almost all kinds of biological activities [10]. In general, Heterocyclic compounds have various hetero atoms such as oxygen, sulphur and nitrogen. which have attracted significant attention of chemists in the past decade because of their extensive range of biological properties as antibacterial [11], antifungal [12], anticancer [13,14]. Also, because of coordination susceptibility of chemical nature of rhodanines and its derivatives, they have been selected as significant case of study [15]. schiff bases are multi-purpose ligands which are produced from primary amines with compounds including carbonyl groups [16]. These compounds due to presence azomethine group in their structure, represent numerous biological activities such as antifungal, antibacterial, anticancer [17]. It was also found that Transition metal complexes formed from the schiff bases ligands possessed different biological activities [18]. In the present study, synthesis and characterization new complexes obtained by novel schiff base ligand of $\mathrm{N}$-amino rhodanine with $\mathrm{Cu}$ (II), $\mathrm{Co}(\mathrm{II}), \mathrm{Ni}(\mathrm{II})$ metal chloride are reported. moreover, The antibacterial and antifungal activities of this ligand and its complexes against four bacteria and two fungi are investigated.

\section{EXPERIMENTAL}

\subsection{Chemicals and apparatus}

All chemicals and solvents used were of analytical grade(AR).All these compounds were purchased from merck company, and were used without any purification. they included copper(II) chloride, cobalt(II) chloride, nickel(II) chloride, N-amino Rhodanine, 2- methoxy- benzaldehyde Elemental microanalyses $(\mathrm{C}, \mathrm{H}, \mathrm{N})$ of the ligand and its complexes were performed using a perkin-Elmer (CHN 2400 elemental analyzer). The ${ }^{1} \mathrm{H}-\mathrm{NMR}$ spectrum was obtained with $\mathrm{Bruker}(300 \mathrm{MH}, 75 \mathrm{MH})$ in DMSO- $d_{6}$ as the solvent and TMS as an internal standard. Infrared IR spectra were recorded on an ABB 2000 FTLA spectrometer using $\mathrm{KBr}$ pellets. Melting points were measured on a BÜCHI Melting point B-540 apparatus.

\subsection{Synthesis of the schiff base ligand (L)}

schiff base ligand $(L)$, synthesized by condensation of a warm solution of 2- metothy-benzaldehyde (10 mmol) with warm solution $(10 \mathrm{mmol})$ of 3 -amino rhodanine in $(30 \mathrm{ml})$ of hot mixture of ethanol-chloroform $(1: 1)$. The resulting mixture was maintained at reflux for 2 hours to ensure complete reaction, and the formed solid precipitates were separated through filtration, and washed several times with ethanol-chloroform mixture, and diethylether. Also dried in a vacuum desiccator over anhydrous $\mathrm{P}_{2} \mathrm{O}_{5}$. The white to yellow product is produced $92 \%$ yield. Structure of the ligand $(\mathrm{L})$ is shown in figure 1 .

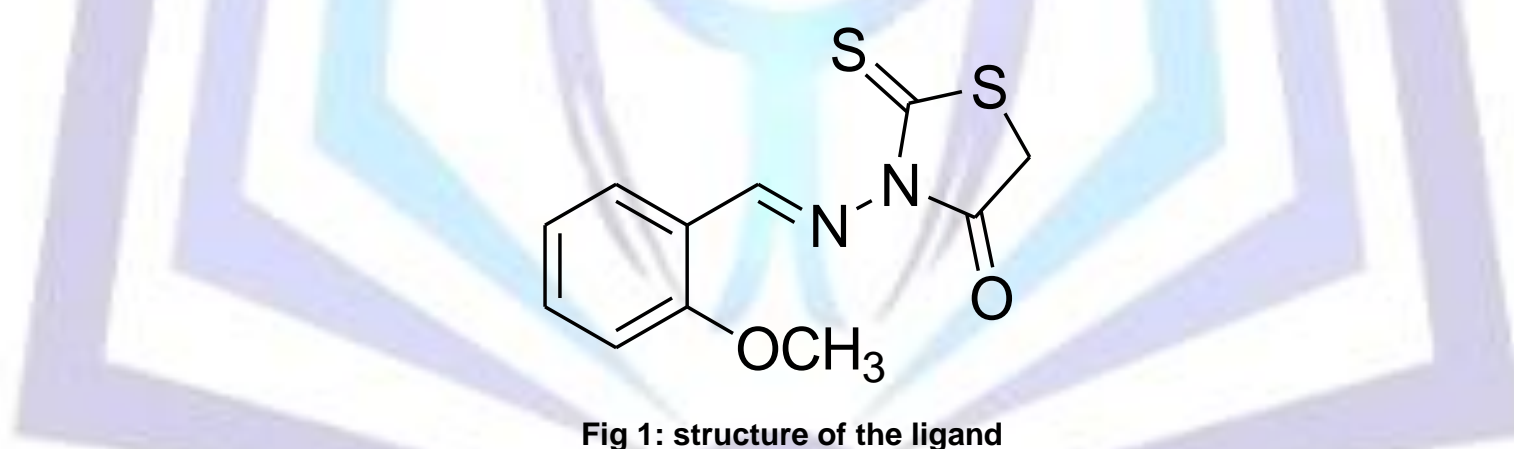

\subsection{Synthesis of the metal complexes}

The $\left[\mathrm{Ni}(\mathrm{L}) \mathrm{Cl}_{2}\left(\mathrm{H}_{2} \mathrm{O}\right)\right]$, [Co(L)Cl $\mathrm{Cl}_{2}$ complexes, were prepared by adding a warm solution of the $\mathrm{NiCl}_{2} \cdot 6 \mathrm{H}_{2} \mathrm{O}, \mathrm{CoCl}_{2} \cdot 6 \mathrm{H}_{2} \mathrm{O}(0.5$ $\mathrm{mmol})$ in a hot ethanol $(3 \mathrm{ml})$ to a warm solution of the schiff base ligand $(0.5 \mathrm{mmol})$ in the chloroform $(6 \mathrm{ml})$. Also, the $\left[\mathrm{Cu}(\mathrm{L}) \mathrm{Cl}_{2}\left(\mathrm{H}_{2} \mathrm{O}\right)\right]$ complex was prepared by mixing warm solution of the $\mathrm{CuCl}_{2} \cdot 6 \mathrm{H}_{2} \mathrm{O}(0.5 \mathrm{mmol})$ in a hot methanol $(7 \mathrm{ml})$ with a warm solution of the schiff base ligand $(0.5 \mathrm{mmol})$ in the chloroform $(7 \mathrm{ml})$. In cases of copper and cobalt complexes, the resulting reaction mixtures were refluxed with constant stirring for 5 hours. But In case of nickel complex, the resulting mixture was refluxed for 2 hours.

\subsection{Microorganisms used}

The microorganisms used in this study are shown in Table 3. Four bacterial (2 Gram-negative and 2 Gram-Positive) and two fungal species were subjected to antimicrobial activity test of the $L$ ligand and its complexes. The bacterial species used in the screening were Salmonella typhi and Vibrio cholera (gram negative) and Staphylococcus aureus and Bacillus subtilis (gram-positive). The fungal species were Aspergillus flavus and Aspergillus nigar.

\subsubsection{Growth conditions}

An inoculum of each bacterial strain was suspended in $25 \mathrm{ml}$ of Mueller-Hinton agar and was shaken at $37^{\circ} \mathrm{C}$ for $24 \mathrm{~h}$. For yeast, malt extract agar was inoculated with test organism and incubated at $28^{\circ} \mathrm{C}$ for $24 \mathrm{~h}$. 


\subsubsection{Determination of antimicrobial activity of the ligand and complexes}

The antibacterial and antifungal activities of the ligand and its metal complexes were studied by disc agar diffusion method [19]. This test was done to determine the sensitivity or resistance of the pathogenic microorganism to the synthesized compounds. The presence or absence of growth around the disks is an indirect measure of the ability of that compound to inhibit that organism. Mueller-Hinton agar (for bacteria) and malt extract agar (for yeast) plates were inoculated with $0.1 \mathrm{ml}$ of an appropriate dilution of the tested culture. Samples $(1 \mathrm{~cm}$ diameter) were suspended in $100 \mathrm{ml}$ of sterile distilled water. $25 \mathrm{ml}$ of each suspension was added to filter paper discs (6 mm diameter), which were placed on the surface of the previously inoculated plates. The plates were incubated at the appropriate temperature for $24 \mathrm{~h}$.

\section{RESULTS AND DISCUSSIONS}

The ligand and complexes were characterized through elemental analyses $(\mathrm{C}, \mathrm{H}, \mathrm{N})$ and IR spectra. The results indicated in very good accordance with those calculated for the propose formulae. The data elemental analyses and melting point is reported in Table 1. Also, the structure of this ligand $(\mathrm{L})$ is demonstrated by ${ }^{1} \mathrm{H}-\mathrm{NMR}$ spectra.

Table 1: Color products, melting point and Analytical data of the ligand $(L)$ and its complexes.

\begin{tabular}{|c|c|c|c|c|c|c|}
\hline \multirow[t]{2}{*}{ Product } & \multirow[t]{2}{*}{$\mathrm{M}: \mathrm{L}$} & \multirow[t]{2}{*}{ Color } & \multirow{2}{*}{$\begin{array}{l}\text { M.P } \\
\left({ }^{\circ} \mathrm{C}\right)\end{array}$} & \multicolumn{3}{|c|}{ \% Cal.(Found) } \\
\hline & & & & $\% \mathrm{C}$ & $\% \mathrm{H}$ & $\% \mathrm{~N}$ \\
\hline $\mathrm{C}_{11} \mathrm{H}_{10} \mathrm{~S}_{2} \mathrm{~N}_{2} \mathrm{O}_{2}$ & & $\begin{array}{l}\text { White } \\
\text { Yellow }\end{array}$ & $207^{\circ} \mathrm{C}$ & $49.61(49.32)$ & $3.78(3.68)$ & $10.52(10.42)$ \\
\hline $\mathrm{Co}_{11} \mathrm{H}_{10} \mathrm{~S}_{2} \mathrm{~N}_{2} \mathrm{O}_{2} \mathrm{Cl}_{2}$ & $1: 1$ & Violet & $232^{\circ} \mathrm{C}$ & 33.35 (34.92) & $2.54(2.50)$ & $7.07(7.12)$ \\
\hline $\mathrm{Cu} \mathrm{C}_{11} \mathrm{H}_{12} \mathrm{~S}_{2} \mathrm{~N}_{2} \mathrm{O}_{3} \mathrm{Cl}_{2}$ & $1: 1$ & $\begin{array}{c}\text { Greenish } \\
\text { black }\end{array}$ & $253^{\circ} \mathrm{C}$ & 31.55 (31.02) & $2.89(2.85)$ & $6.69(6.58)$ \\
\hline $\mathrm{Ni} \mathrm{C}_{11} \mathrm{H}_{12} \mathrm{~S}_{2} \mathrm{~N}_{2} \mathrm{O}_{3} \mathrm{Cl}_{2}$ & $1: 1$ & $\begin{array}{c}\text { Greenish } \\
\text { Yellow }\end{array}$ & $290^{\circ} \mathrm{C}$ & $31.92(32.12)$ & $2.92(2.86)$ & $6.77(6.72)$ \\
\hline
\end{tabular}

The result ${ }^{1} \mathrm{H}$-NMR spectra of the ligand $(\mathrm{L})$ that dissolved in DMSO, represented in Table 2 . The aromatic proton signals have resonance at 7.06-7.99 ppm, and the azomethine proton exhibits at $8.9 \mathrm{ppm}$. Also, protons signal due to presence methoxy $\left(\mathrm{OCH}_{3}\right)$, and methylene ring $\left(\mathrm{CH}_{2}\right)$ of the ligand structure appear at $3.78 \mathrm{ppm}$ and 4.29 ppm, respectively. Also, absence Hydrogen belongs to amine group at resonance 6 - ppm, confirms the aldoly reaction between $\mathrm{N}$-amino rhodanine with 2-methoxy benzaldehyde and production of schiff base ligand through combining amine group with carbonyl group.

Table 2: ${ }^{1} \mathrm{H}-\mathrm{NMR}$ data for the ligand (L) in DMSO solution( $\left.\delta, \mathrm{ppm}\right)$

\begin{tabular}{|c|c|c|c|c|}
\hline Ligand & $\mathbf{C H = N}$ (azomethine) & $\mathbf{O C H}_{3}$ (methoxy) & $\mathbf{C H}_{2}$ (ring) & Aromatic protons \\
\hline $\mathrm{L}$ & 8.9 & 3.78 & 4.29 & $7.06-7.99$ \\
\hline
\end{tabular}

The important IR bands of the ligand and its metal complexes are collected in Table 3 . In the structure of the ligand, significant functional groups that have coordination susceptibility, assigned to $\mathrm{C}=\mathrm{S}, \mathrm{C}=\mathrm{O}$ and $\mathrm{CH}=\mathrm{N}$ bands. These bands located at $1252 \mathrm{~cm}^{-1} 1730 \mathrm{~cm}^{-1}, 1598 \mathrm{~cm}^{-1}$ respectively. Also, in the Cu complex, the presence of bands revealed at $1155-$ $\mathrm{cm}^{-1}, 1591 \mathrm{~cm}^{-1}, 1719 \mathrm{~cm}^{-1}$ are the strong indication of $\mathrm{C}=\mathrm{S}, \mathrm{CH}=\mathrm{N}, \mathrm{C}=\mathrm{O}$ functional groups respectively. In this complex, significant shift to lower frequencies for $\mathrm{C}=\mathrm{S}, \mathrm{C}=\mathrm{O}$ and $\mathrm{CH}=\mathrm{N}$ bands, indicating coordination of the metal ion with the thiocarbonyl sulphur atom, carbonyl oxygen atom and azomethine nitrogen atom. In the Co complex, absorption bands are showed at $1723 \mathrm{~cm}^{-1} 1237 \mathrm{~cm}^{-1}$ and $1596 \mathrm{~cm}^{-1}$ that are assigned to $\mathrm{C}=\mathrm{O}, \mathrm{C}=\mathrm{S}, \mathrm{CH}=\mathrm{N}$ respectively. in this complex $\mathrm{C}=\mathrm{O}, \mathrm{C}=\mathrm{S}$ bands shift to lower frequencies, that consistent with coordination through the carbonyl oxygen atom and thiocarbonyl sulphur atom. In the Ni complex, the bands due to $\mathrm{C}=\mathrm{O}, \mathrm{C}=\mathrm{S}, \mathrm{CH}=\mathrm{N}$ were observed at $1718 \mathrm{~cm}^{-1}, 1236 \mathrm{~cm}^{-1}$ and $1589 \mathrm{~cm}^{-1}$ respectively. These bands in this complex, comparing with ligand were shifted to lower frequencies. This is evident by the coordination through the carbonyl oxygen atom, thiocarbonyl sulphur atom and azomethine nitrogen atom. Also, $\mathrm{Ni}$ and Cu complexes, a broad band appeared in the range $3240-3493 \mathrm{~cm}^{-1}$ is due to the $(\mathrm{OH}) \mathrm{group}$, and indicates the presence of water molecules.

Table 3: IR spectra of the ligand $L$ and its metal complexes.

\begin{tabular}{|c|c|c|c|c|}
\hline Compound & $\mathbf{v}(\mathbf{C}=\mathbf{O})$ & $\mathbf{v}(\mathbf{C}=\mathbf{S})$ & $\mathbf{v}(\mathbf{C H}=\mathbf{N})$ & $\mathbf{v}(\mathbf{O H})\left(\mathbf{H}_{2} \mathbf{O}\right)$ \\
\hline $\mathrm{L}$ & $1730 \mathrm{~cm}^{-1}$ & $1252 \mathrm{~cm}^{-1}$ & $1598 \mathrm{~cm}^{-1}$ & \\
\hline$\left[\mathrm{Cu}(\mathrm{L}) \mathrm{Cl}_{2}\left(\mathrm{H}_{2} \mathrm{O}\right)\right]$ & $1719 \mathrm{~cm}^{-1}$ & $1155 \mathrm{~cm}^{-1}$ & $1591 \mathrm{~cm}^{-1}$ & $3286 \mathrm{~cm}^{-1}$ \\
\hline$\left[\mathrm{Co}(\mathrm{L}) \mathrm{Cl}_{2}\right]$ & $1723 \mathrm{~cm}^{-1}$ & $1237 \mathrm{~cm}^{-1}$ & $1596 \mathrm{~cm}^{-1}$ & \\
\hline$\left[\mathrm{Ni}(\mathrm{L}) \mathrm{Cl}_{2}\left(\mathrm{H}_{2} \mathrm{O}\right)\right]$ & $1718 \mathrm{~cm}^{-1}$ & $1236 \mathrm{~cm}^{-1}$ & $1589 \mathrm{~cm}^{-1}$ & $3358 \mathrm{~cm}^{-1}$ \\
\hline
\end{tabular}


The elemental analysis and IR spectra data propose the structure of the prepared complexes, that are shown in Figure 2.

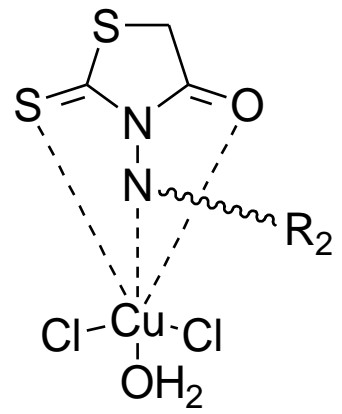

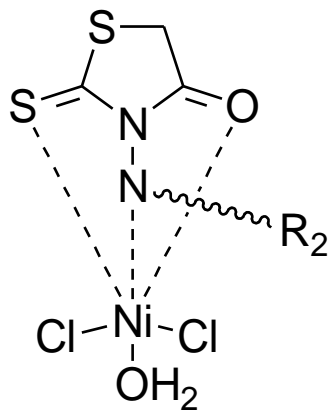<smiles></smiles><smiles>[R]=Cc1ccccc1OC</smiles>

Fig 2: suggested structure of complexes

\subsection{Biological activity of the ligand and its complexes}

As shown in Table 3 four bacterial ( 2 Gram- negative and 2 Gram-positive) and two fungal were tested to antimicrobial activity ligand and its complexes.

Table 3. The kinds of microorganisms used in this study.

\begin{tabular}{|c|c|c|}
\hline Microorganisms & Classification & Abbreviation \\
\hline Salmonella typhi & Gram- negative & St \\
\hline Vibrio cholera & Gram- negative & Vc \\
\hline Staphylococcus aureus & Gram- positive & Sa \\
\hline Bacillus subtilis & Gram- positive & Bs \\
\hline Aspergillus flavus & Yeast & Af \\
\hline Aspergillus nigar & Yeast & An \\
\hline
\end{tabular}

The antibacterial and antifungal activity for the ligand and its corresponding metal complexes are shown in Table 4. Disc agar diffusion method was carried for ligand and its complexes activities against the microorganisms and compared with Ampicillin.

Table 4. Antimicrobial activities of ligand (L) and its complexes.

\begin{tabular}{|c|c|c|c|c|c|c|}
\hline Compounds & St & Vc & Sa & Bs & Af & An \\
\hline$(\mathrm{L})$ & - & - & - & - & - & - \\
\hline CuL & ++ & ++ & +++ & ++++ & +++ & ++ \\
\hline CoL & +++ & ++ & +++ & +++ & ++ & ++ \\
\hline NiL & +++ & ++ & ++++ & ++++ & ++ & ++ \\
\hline Ampicillin & ++++ & ++++ & ++++ & ++++ & +++ & +++ \\
\hline
\end{tabular}

(-) $\mathrm{n}$ zone of inhibition, (+) 1-10 mm zone of inhibition, (++) 11-20 mm zone of inhibition

(+++) 21-30 mm zone of inhibition and (++++) 31-40 mm zone of inhibition. 
As shown in Table 4, diameter of inhibition zone $(\mathrm{mm})$ including the disc diameter was measured for each treatment. The ligand $(\mathrm{L})$ showed no antimicrobial activity at all against the microorganisms. The CuL and NiL complexes exhibited the maximum antibacterial and antifungal activities. While the CoL complex showed moderate antimicrobial activity against all organisms used in this study. Ampicillin showed highest antimicrobial activity compared to other compounds. The findings indicated that the CuL, NiL and CoL complexes have good biological activity but the ligand (L) did not had any activity against the microorganisms under identical experimental conditions. These results can be explained by Tweedy's chelation theory. In fact, this theory says, the chelation can raises the ability of a complex to penetrate a cell membrane [20].

\section{CONCLUSION}

Chelation formation reduces the polarity of central metal ion due to the partial sharing of its positive charge with donor groups. Further, it increases the delocalization of $\pi$-electrons over the whole chelate ring and increases the penetration of the complexes in to lipid membrane [21]. In this study, We conclude that the complexes show more anti-bacterial and antifungal activities but ligand do not have any activity against some organisms under similar experimental conditions.

\section{ACKNOWLEDGMENTS}

The authors would like to thank the K. N. Toosi University of Technology and Babol University of Medical Sciences for their facilities.

\section{REFERENCES}

[1] R.C. Moellering Jr. 2008. Antimicrobial agent in treatment of MRSA infections. Current treatment options for community-acquired methicilin-resistant staphylococcus aureus infection. Clin. Infect. Dis. 46, 1032-1037.

[2] Sim, M. M., Ng, S. B., Buss, A. D., Crasta, S. C., Goh, K. L., Lee, S. K. 2002. Benzylidene Rhodanines as novel inhibitors of UDP-N-acetylmuramate/ L-alanine ligase. Bioorg. Med. Chem. Lett. 12, 697-699.

[3] Petrikaite, V., Tarasevicius, E., Pavilonis, A. 2007. New ethacridine derivatives as the potential antifungal and antibacterial preparations. Medicina (Kaunas) 43, 657-663.

[4] Heng, S., Tieu, W., Hautmann, S., Kuan, K., Pedersen, D. S. 2011. New cholesterol esterase inhibitors based on rhodanine and thiazolidinedione scaffolds. Bioorg .Med. Chem. 19, 7453-7463.

[5] Rajamaki, S., Innitzer, A., Falciani, C., Tintori, C., Christ, F. 2009. Exploration of novel thiobarbituric acid-, rhodanineand thiohydantoin-based HIV-1 integrase inhibitors. Bioorg. Med. Chem. Lett. 19, 3615-3618.

[6] Ramkumar, K., Yarovenko, VN., Nikitina, AS., Zavarzin, IV., Krayushkin, MM. 2010. Design, synthesis and structureactivity studies of rhodanine derivatives as HIV-1 integrase inhibitors. Molecules. 15, 3958-3992

[7] Alegaon, SG., Alagawadi, KR., Sonkusare, PV., Chaudhary, SM., Dadwe, DH. 2012. Novel imidazo [2,1b] $[1,3,4]$ thiadiazole carrying rhodanine-3-acetic acidas potential antitubercular agents. Bioorg. Med. Chem. Lett. 22, 1917-1921.

[8] Kumar, G., Parasuraman, P., Sharma, SK., Banerjee, T., Karmodiya, K. 2007. Discovery of a rhodanine class of compounds as inhibitors of Plasmodium falciparum enoyl-acyl carrier protein reductase. J. Med. Chem. 50, 26652675.

[9] Sudo, K., Masumoto, Y., Matsushima, M., Fujwara, M., Shimotohno, K., Shigerta S., Yokora, T.1997. Novel Hepatitis C Virus Protease Inhibitors: Thiazolidine Derivatives. Biochem. Biophys. Res. Comm. 238, 643-647.

[10] Kumarjain, A., Vaidya, A., Ravichandran, V. 2012. Recent developments and biological activities of thiazolidinone derivatives: A review. J. Bioorg. Med. chem. 20, 3378-3395.

[11] Liu, JC., Zheng, CJ., Wang, MX., Li, YR., Ma, LX. 2014. Synthesis and evaluation of the antimicrobial activities of 3((5-phenyl-1,3,4-oxadiazol-2-yl) methyl)-2-thioxothiazolidin-4-one derivatives. Eur. J. Med. Chem. 74, 405-410.

[12] Siddiqui, IR., Singh, PK., Singh, J. 2005. Facile synthesis and fungicidal activity of novel 4,4'-bis[2"-(5"'-substituted rhodanin-3"'-yl)thiazol-4"-yl] bibenzyls. Indian J. Chem. 44, 2102-2106.

[13] Azizmohammadi, M., Khoobi, M., Ramazani, A., Emami, S., Zarrin, A. 2013. 2H-chromene derivatives bearing thiazolidine-2,4-dione, rhodanine or hydantoin moieties as potential anticancer agents. Eur. J. Med Chem. 59, 15-22.

[14] Chandrappa, S1., Kavitha, CV., Shahabuddin, MS., Vinaya, K., Ananda Kumar,CS. 2009. Synthesis of 2-(5-((5-(4chlorophenyl)furan-2-yl)methylene)-4-oxo-2-thioxothiazolidin-3-yl)acetic acid derivatives and evaluation of their cytotoxicity and induction of apoptosis in human leukemia cells. Bioorg. Med. Chem. 17, 2576-2584.

[15] El-Bindary, A. A., El-Sonbati, A. Z. 2000. Synthesis and Properties of Complexes of Copper(II), Nickel(II), Cobalt(II) and Uranyl lons with 3-(P- Tolylsulphonamido)rhodanine. Polish. J. Chem. 74, 615-620.

[16] Arulmurugan, S., kavitha, H., Venkatraman B.R. 2010. Biological activities of schiff base and its complexes: A review. Rasayan J. Chem. 3, 385-410. 
[17] Annapoorani, S., Krishnan, C. 2013. Synthesis and spectroscopic studies of trinuclear N4 Schiff base complexes international. J. Chem. Tech. Res. 5, 180-185.

[18] Momose, Y., Meguro, K., Ikeda, H., Hatanaka, C., Oi, S., Sohda, T. 1991. Studies on Antidiabetic Agents. X. Synthesis and Biological Activities of Pioglitazone and Related Compounds, Chem. Pharm. Bull. 39, 1440-1445.

[19] Feng-Hua, L., Guang-Hua, Z., Hong-Xing, W., Hai, L., Xiang-Xia, W., Shou-Rong, Z., Hua-Kuan, L. 2006. Synthesis, characterization and biological activity of lanthanum(III) complexes containing 2-methylene-1,10-phenanthroline units bridged by aliphatic diamines. J. Inorg. Biochem. 100, 36-43.

[20] Fahmi, N., Gupta, I. J., Singh, R. V. 1998. Sulfur bonded palladium (II) and platinum (II) complexes of biologically potent thioamides. Phosphours Sulfur and Silicon. 132, 1-8.

[21] Tumer, M., Ekinci, D., Tumer F., Bulut, A. 2007. Synthesis, characterization and properties of some divalent metal(II) complexes: Their electrochemical, catalytic, thermal and antimicrobial activity studies. Spectrochimica Acta Part $A$ : Molecular and Biomolecular Spectroscopy, 67, 916-929. 